\title{
Enrichment of nutrients, exopolymeric substances and microorganisms in newly formed sea ice on the Mackenzie shelf
}

\author{
Andrea Riedel ${ }^{1, *}$, Christine Michel $^{2}$, Michel Gosselin $^{1}$, Bernard LeBlanc $^{2}$ \\ ${ }^{1}$ Institut des sciences de la mer (ISMER), Université du Québec à Rimouski, 310 allée des Ursulines, Rimouski, \\ Québec G5L 3A1, Canada \\ ${ }^{2}$ Fisheries and Oceans Canada, Freshwater Institute, 501 University Crescent, Winnipeg, Manitoba R3T 2N6, Canada
}

\begin{abstract}
Newly formed sea ice was sampled at 32 stations on the Mackenzie shelf, between 30 September and 19 November 2003. At each station, sea ice and surface waters were analysed to assess the concentration and enrichment of nutrients, exopolymeric substances (EPS, measured with Alcian blue), chlorophyll a (chl a), autotrophic and heterotrophic protists, and heterotrophic bacteria. Dark incubations were also conducted to estimate net heterotrophic $\mathrm{NH}_{4}$ regeneration rates in sea ice $<5 \mathrm{~cm}$ thick. Large $(\geq 5 \mu \mathrm{m})$ autotrophs were selectively enriched during sea-ice formation, having the highest average enrichment index $\left(I_{\mathrm{S}}=62\right)$, although heterotrophic protists $\left(I_{\mathrm{S}}=19\right)$, EPS $\left(I_{\mathrm{S}}=17\right)$, bacteria $\left(I_{S}=6\right)$ and dissolved inorganic nitrogen $\left(I_{S}=3\right.$ to 5$)$ were also significantly enriched in the sea ice. Significant relationships were observed between sea-ice EPS and total chl a concentrations $(\mathrm{r}=0.59, \mathrm{p}<0.001)$ and between sea-ice EPS and $\geq 5 \mu \mathrm{m}$ autotroph enrichment indices $(\mathrm{r}=0.48, \mathrm{p}<$ 0.01), suggesting that EPS were actively produced by algae entrapped in the sea ice. These relationships also suggest that the presence of EPS may enhance the selective enrichment of large autotrophs. Heterotrophic regeneration contributed to the observed enrichment of $\mathrm{NH}_{4}$ in the sea ice, with an average regeneration rate of $0.48 \mu \mathrm{M} \mathrm{d}^{-1}$, contributing $67 \%$ of the sea-ice $\mathrm{NH}_{4}$ concentrations. In the newly formed ice, $\mathrm{NH}_{4}$ regeneration was coupled to $\mathrm{NO}_{3}$ and $\mathrm{Si}(\mathrm{OH})_{4}$ consumption and was significantly related to EPS concentrations $(r=0.87, \mathrm{p}<0.05)$. Our data suggest that EPS enhance $\mathrm{NH}_{4}$ regeneration by acting as a carbon source for sea-ice heterotrophs or a substrate for sea-ice bacteria.
\end{abstract}

KEY WORDS: Newly formed sea ice · Arctic · Exopolymeric substances · EPS · Enrichment · Ammonium $\cdot$ Regeneration $\cdot$ Protists $\cdot$ Bacteria Resale or republication not permitted without written consent of the publisher

\section{INTRODUCTION}

High biomasses of algae and other protists can accumulate in Arctic first-year sea ice in the spring (i.e. seaice algal blooms in April and May; Smith \& Herman 1991, Michel et al. 1996, Melnikov et al. 2002). However, algal cells and other microorganisms are present within the sea ice for several months prior to the beginning of the spring bloom (Gradinger \& Ikävalko 1998, Melnikov et al. 2002). Microorganisms from the water column and even the benthos are incorporated in the sea ice during its formation, which occurs primarily between September and December on the Canadian Arctic shelves (Canadian Ice Services 2002). Organisms incorporated in the sea ice during the fall can overwinter in the sea-ice matrix and are the founding members of the spring bloom community (Zhang et al. 1998).

In the Arctic Ocean, suspension freezing (Campbell \& Collin 1958) is the most important process for the 
accumulation of inorganic sediments within the sea ice (Reimnitz et al. 1992). This same process leads to the accumulation of microorganisms in newly formed sea ice (Garrison et al. 1983, Reimnitz et al. 1993). Suspension freezing occurs under cold, turbulent conditions, which can lead to a supercooled water column. Once supercooled, frazil sea ice (i.e. suspended ice crystals) forms in the water column and rises to the surface where it accumulates as new ice with columnar ice growth continuing after frazil formation ends (Weeks \& Ackley 1982, Eicken 2003).

Inorganic sediments and microorganisms can adhere to individual frazil crystals as they rise through the water column. Frazil formation may occur as deep as 25 to $30 \mathrm{~m}$; thus, small particles can be picked up directly from the benthos on shallow shelves (Reimnitz et al. 1992). Large quantities of sediment and benthic microorganisms can also be incorporated into newly formed sea ice when frazil adheres to coarse particles on the sea floor, forming unconsolidated masses of anchor ice (Reimnitz et al. 1992). Under calm conditions the anchor ice, along with entrapped particles, can float to the surface and become incorporated into the newly formed sea ice. The formation of anchor ice and deep frazil can explain the numerous benthic algal species found in Arctic sea ice during the spring bloom (von Quillfeldt et al. 2003).

The harvesting or scavenging of cells by frazil crystals during early stages of ice formation can cause microorganisms to accumulate in the sea ice at concentrations orders of magnitude greater than in the surface water (Garrison et al. 1983, Gradinger \& Ikävalko 1998). The extent to which cells become enriched within newly formed sea ice is dependent upon any cell incorporation, growth or loss (e.g. grazing) processes, associated with the developing sea ice. The incorporation of microorganisms can be selective with preferences for different cell sizes or taxa (Weissenberger \& Grossmann 1998). Enrichment is usually highest for algal cells, as compared to other microorganisms, and selective enrichment of large-sized cells, such as diatoms, has been observed in Arctic sea ice (Gradinger \& Ikävalko 1998, von Quillfeldt et al. 2003). Small cells, such as bacteria, can also be enriched within newly formed sea ice. However, bacterial enrichment in newly formed sea ice has not been consistently observed and is usually associated with high algal enrichment (Grossmann \& Dieckmann 1994, Weissenberger \& Grossmann 1998).

Gradinger \& Ikävalko (1998) suggest that cellsurface characteristics (e.g. stickiness) can influence cell selectivity during sea-ice formation. Grossmann \& Dieckmann (1994) also propose that bacterial incorporation into newly formed sea ice could be mediated through their attachment to the surface of algal cells or their mucus coatings. These interactions indicate a potentially important role for exopolymers in the selectivity and enrichment of sea-ice assemblages. Exopolymers are a diverse group of sticky compounds, which include gel-like polysaccharides and glycoproteins, produced by phytoplankton (Passow 2002a), sea-ice algae (Krembs et al. 2002, Meiners et al. 2003, Riedel et al. 2006) and, in copious amounts, by benthic diatoms (Smith \& Underwood 1998). These exopolymers can exist as a gel surrounding cells or as free colloidal substances.

The terminology used to describe these exopolymers varies in the published literature. In the present study, the term exopolymeric substances (EPS) is used to specifically represent particulate $(>0.4 \mu \mathrm{m})$ exopolysaccharides as measured by the Alcian blue method (Passow \& Alldredge 1995). The Alcian blue method was first used to measure transparent exopolymer particles (TEP), which refer primarily to discrete particles in the water column formed abiotically from dissolved precursors (for review: Decho 1990, Passow 2002b). The exopolymers investigated in the present study may not be discrete particles, but rather could be associated with cell surfaces in the sea ice, water column, or benthos during the period of ice formation. Therefore, the particles measured by the Alcian blue method in this study will be referred to as EPS.

Newly formed sea ice can also be enriched in dissolved inorganic and organic nutrients. However, nutrient enrichment in newly formed sea ice is not expected to result from physical incorporation processes, but rather from in situ nutrient regeneration (Gradinger \& Ikävalko 1998). Heterotrophic nutrient regeneration by micro- or nano-sized protists and bacteria (Glibert 1993) can result in high nitrogen concentrations within the sea ice (Harrison et al. 1990, Arrigo et al. 1995, Conover et al. 1999).

Community dynamics and trophic interactions, including nutrient cycling, within newly formed sea ice are still poorly understood, especially for very thin sea ice (i.e. $<10 \mathrm{~cm}$ ) formed on the extensive Arctic shelves. Therefore, the fall and winter contribution of sea-ice assemblages to Arctic Ocean carbon cycling is largely unknown. In the present study, we investigated microbial interactions and assessed the enrichment of nutrients, EPS and microorganisms in newly formed sea ice, between 0.1 and $40 \mathrm{~cm}$ thick. We hypothesised that EPS could influence both physical and biogeochemical interactions in the sea ice due to their stickiness and high carbon content, and that any enrichment in dissolved nitrogen in newly formed sea ice would result from heterotrophic activity. In order to test these hypotheses, this study was centred around 3 main objectives: (1) assess the variability in the concentration and enrichment of nutrients, EPS, autotrophic and 
heterotrophic protists and bacteria in newly formed sea ice on the Mackenzie shelf, in the high Canadian Arctic; (2) evaluate and identify any selectivity based on cell size; and (3) assess the role of heterotrophs in nitrogen regeneration in newly formed sea ice.

\section{MATERIALS AND METHODS}

Sampling and analyses. This study was conducted on the Mackenzie shelf, Canadian Arctic, from 30 September to 19 November 2003, as part of the Canadian Arctic Shelf Exchange Study (CASES) on board the CCGS 'Amundsen'. Newly formed sea ice and surface waters were collected at 32 stations (Fig. 1). The seaice samples belonged to 1 of 4 stages of ice development, which vary in structure and/or thickness. The stages of ice development, as described in MANICE (Canadian Ice Services 2005), and the thicknesses observed during this study are as follows: new ice $(0.1$ to $8.4 \mathrm{~cm}, \mathrm{n}=6)$, nilas ( 0.1 to $9.0 \mathrm{~cm}, \mathrm{n}=9)$, young ice (11 to $27.3 \mathrm{~cm}, \mathrm{n}=13$ ) and thin first-year ice (31.4 to $38.8 \mathrm{~cm}, \mathrm{n}=4)$.

Newly formed sea ice $<7 \mathrm{~cm}$ thick was sampled with a strainer, with the entire ice thickness being retained for analyses. Newly formed congelation sea ice, $\geq 7 \mathrm{~cm}$ thick, was sampled with a manual ice corer (Mark II coring system, Kovacs Enterprise, $9 \mathrm{~cm}$ internal diameter), with only the bottom $3 \mathrm{~cm}$ of each core kept for analysis. Sea ice was melted in $0.2 \mu \mathrm{m}$ filtered seawater collected at the surface at the time of sampling, to minimise osmotic stress during the melting process (Garrison \& Buck 1986). A separate sea-ice subsample, to which no filtered seawater was added, was kept in a sterile container for later salinity and nutrient analyses. At each station, seawater just under the ice was also collected with a clean container or Niskin bottle. Seaice and surface-water subsamples were analysed for salinity, nutrients $\left(\mathrm{NH}_{4}, \mathrm{NO}_{2}, \mathrm{NO}_{3}, \mathrm{Si}(\mathrm{OH})_{4}\right.$ and $\left.\mathrm{PO}_{4}\right)$, EPS, chlorophyll a (chl a), and the abundance of autotrophic and heterotrophic protists, as well as heterotrophic bacteria. When necessary, sea-ice concentrations were corrected for the dilution from the addition of seawater during the melting process.

Salinity was determined with an Autosal (Model 8400B) analyser. Nutrient samples were stored at $4^{\circ} \mathrm{C}$ in the dark and analysed within $24 \mathrm{~h}$ on a Bran+ Luebbe III Autoanalyser. Chl a concentration was determined fluorometrically (10AU Turner Designs) on duplicate subsamples filtered onto Whatman GF/F filters (nominal pore size of $0.7 \mu \mathrm{m}$, total chl a) and $5 \mu \mathrm{m}$ Poretics polycarbonate membranes ( $>5 \mu \mathrm{m} \mathrm{chl} \mathrm{a),} \mathrm{after}$ $24 \mathrm{~h}$ extraction in $90 \%$ acetone at $5^{\circ} \mathrm{C}$ in the dark (Parsons et al. 1984).

Triplicate EPS subsamples were filtered onto $47 \mathrm{~mm}$ diameter, $0.4 \mu \mathrm{m}$ polycarbonate filters and stained with Alcian blue. EPS concentrations were measured colorimetrically $(787 \mathrm{~nm})$ after a $2 \mathrm{~h}$ extraction in $80 \% \mathrm{H}_{2} \mathrm{SO}_{4}$

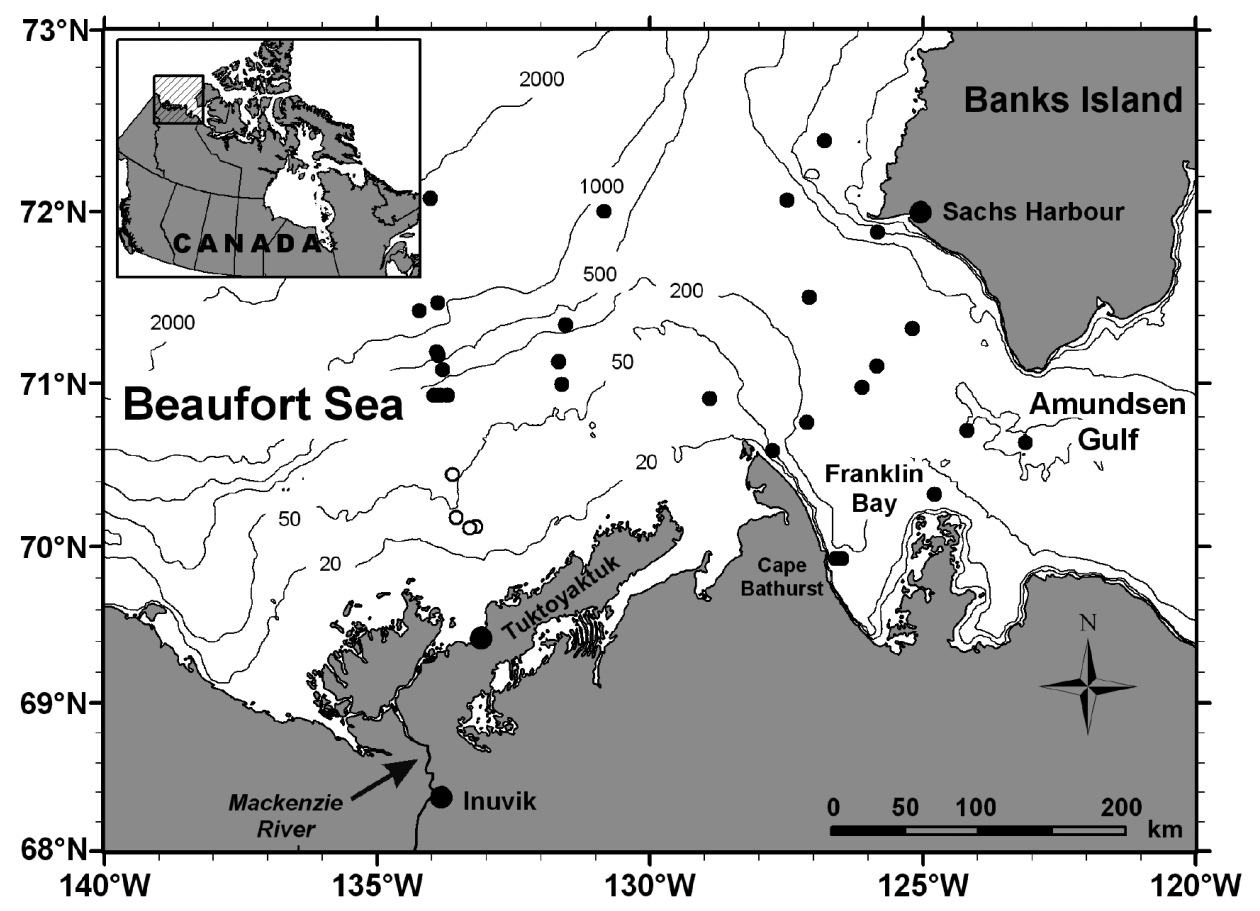

Fig. 1. Locations of sampling stations on the Mackenzie shelf, in fall 2003. Open circles indicate stations in closest proximity to the Mackenzie River (see 'Results' for details). Depth contours in metres 
and were recorded as gum xanthan equivalents ( $\mu \mathrm{g}$ xeq. $\mathrm{l}^{-1}$; Passow \& Alldredge 1995). The addition of $0.2 \mu \mathrm{m}$ filtered seawater during the melting process may have introduced dissolved EPS, which could reassemble during the filtering process. However, this would represent only a minimal addition of EPS due to low EPS concentrations in the surface water.

Epifluorescence microscopy was used to count freeliving and filamentous bacteria, as well as autotrophic and heterotrophic protists (Sherr et al. 1993). Bacteria and protist samples were stained with DAPI $(4,6-$ diamidino-2-phenylindole) at a final concentration of $1 \mu \mathrm{g} \mathrm{ml}^{-1}$, filtered onto 0.2 or $0.8 \mu \mathrm{m}$, black Nuclepore filters, respectively, and stored at $-80^{\circ} \mathrm{C}$. Heterotrophic, free-living and filamentous bacteria were enumerated in 10 fields of duplicate subsamples at $1000 \times$ magnification. A subsample of 200 bacteria filaments was measured with an image analysis system (Image Pro 5.1) to estimate the average and range of filament length.

Autotrophic and heterotrophic protists were counted at $400 \times$ and $1000 \times$ magnification. On average, a minimum of 75 cells was counted. Autotrophic cells were separated into 2 size classes, i.e. $<5 \mu \mathrm{m}$ (mean diameter $=2.5 \mu \mathrm{m})$ and $\geq 5 \mu \mathrm{m}$ (mean diameter $=27 \mu \mathrm{m})$. The abundance of cells $\geq 5 \mu \mathrm{m}$ was determined from the average cell counts at the 2 magnifications, whereas the abundance of cells $<5 \mu \mathrm{m}$ in diameter was obtained from cell counts at $1000 \times$ magnification only. Autotrophic cells were identified by chlorophyll autofluorescence (red fluorescence) under blue light excitation. This counting method cannot rule out potential mixotrophy in these organisms. The heterotrophic protists were generally $\geq 5 \mu \mathrm{m}$ in diameter (mean diameter $=12 \mu \mathrm{m}$ ) and, consequently, were not separated into size classes.

Semi-quantitative estimates of inorganic sediment abundances in the sea ice were performed from visual inspection of 10 fields at $400 \times$ magnification. Three categories of sediment abundance were defined based on the number of sediment particles observed in each square of the ocular grid (low: $<5$, mid: 5 to 10 , high: $>10$ ). These semi-quantitative estimates of sediment abundances were used for comparative purposes only; no attempt was made to obtain quantitative estimates of sediment concentrations.

Enrichment indices $\left(I_{\mathrm{S}}\right)$ for nutrients, EPS, chl $a$, protists and bacteria were calculated according to Gradinger \& Ikävalko (1998). The enrichment calculations include a salinity factor, since brine loss can alter the concentration of microorganisms and nutrients during sea-ice formation. Enrichment indices were calculated such that:

$$
I_{\mathrm{S}}=\left(X_{\mathrm{i}} / S_{\mathrm{i}}\right) \times\left(S_{\mathrm{w}} / X_{\mathrm{w}}\right)
$$

where $X_{\mathrm{i}}$ and $X_{\mathrm{w}}$ are the concentrations or abundances of each variable in the ice and water, respectively, and $S_{\mathrm{i}}$ and $S_{\mathrm{w}}$ are the salinities of the ice and water, respectively. Enrichment indices indicate the degree to which the concentration or abundance of a variable has increased (e.g. $I_{\mathrm{S}}=3$ is a 3 -fold increase) despite implied losses due to desalinisation. An index equal to 1 indicates a similar change in the variable concentration and salinity. Enrichment indices comprise multiple processes that can influence concentrations or abundances within the newly formed sea ice, including physical incorporation, brine drainage, grazing, reproduction and sampling artefacts (Gradinger \& Ikävalko 1998).

Regeneration rates. Net ammonium regeneration $\left(\mu \mathrm{M} \mathrm{d}^{-1}\right)$ by heterotrophic microorganisms in newly formed sea ice was estimated in 7 dark incubation experiments conducted between 30 September and 18 October 2003. The new sea-ice samples were between 0.1 and $3.0 \mathrm{~cm}$ thick and were either new ice or dark nilas. Dark incubations of melted samples were conducted for $24 \mathrm{~h}$ at $0^{\circ} \mathrm{C}$ following a $1 \mathrm{~h}$ acclimatisation period.

For each experiment, the sea ice was partitioned into 5 subsamples in sterile Whirl-Pak bags (Nasco) and slowly melted in the dark without the addition of filtered seawater, to avoid nitrogen contamination. Slow melting, over a $24 \mathrm{~h}$ period, was imperative to protect heterotrophic microorganisms, which are sensitive to osmotic stress (Garrison \& Buck 1986). Ammonium concentrations were analysed every $6 \mathrm{~h}$, for $24 \mathrm{~h}$, using a different subsample at each time point, thus eliminating potential contamination during the time-series subsampling.

Net ammonium regeneration rates were determined from the slope of the change in $\mathrm{NH}_{4}$ concentrations over the $24 \mathrm{~h}$ experimental period (Model I linear regression; Sokal \& Rohlf 1995). In 4 of the 7 experiments, $\mathrm{NO}_{3}$ and $\mathrm{Si}(\mathrm{OH})_{4}$ consumption rates were also estimated from the slope of the change in the concentrations of these nutrients over the $24 \mathrm{~h}$ period. $\mathrm{Chl} \mathrm{a}_{\text {, }}$ bacteria and protist samples were collected at the beginning and end of every experiment to monitor any changes in abundance during the experiments. Nutrient and chl a concentrations and bacterial and heterotrophic protist abundances were analysed as described above.

Statistical analyses. Wilcoxon's signed ranks tests were used to determine if enrichment indices were significantly different from 1 (Sokal \& Rohlf 1995). Model II linear regressions (reduced major axis) were used to evaluate relationships between measured variables. This method takes into account that both independent and dependent variables are subject to analytical measurement errors (Sokal \& Rohlf 1995). In 
order to test for significant differences in biochemical properties between stages of sea-ice development (new ice, nilas, young ice, thin first-year ice) and between classes of sea-ice thickness $(<10,10$ to 20 , $>20 \mathrm{~cm}$ ), 1-way analyses of variance (ANOVAs) and multiple comparison test of means (Tukey's honestly significant difference [HSD] test for unequal sample sizes; Sokal \& Rohlf 1995) were performed. For all parametric statistics, the data were log-transformed when necessary in order to meet the assumptions of homogeneity of variance and normality of distribution required for the analyses. All statistical analyses were carried out using JMP (SAS Institute).

\section{RESULTS}

\section{Physical and chemical environment}

Salinity, nutrient concentrations and ratios, and the abundance of protists and bacteria in the sea ice and surface waters are summarised in Table 1. Bulk salinity was consistently lower in the new ice (4.6 to 22) as compared to surface waters (17 to 34 ). Surface-water salinities were lowest (17 to 21 ) at the sites in closest proximity to the Mackenzie River (open circles in Fig. 1).

Ammonium was the most abundant source of dissolved inorganic nitrogen within the sea ice and surface waters, followed by $\mathrm{NO}_{3}$ and $\mathrm{NO}_{2}$ (Table 1). $\mathrm{Si}(\mathrm{OH})_{4}$ concentrations ranged between 0 and $11.7 \mu \mathrm{M}$ in the sea ice and reached a value of $25.8 \mu \mathrm{M}$ in the surface waters. $\mathrm{NO}_{3}: \mathrm{PO}_{4}$ molar ratios averaged 1.3 and 1.0 in the sea ice and surface waters, respectively (Table 1). These ratios were significantly lower than the Redfield ratio (Redfield et al. 1963) of $16 \mathrm{~N}$ to $1 \mathrm{P}$ (Wilcoxon's signed ranks, $\mathrm{p}<0.001$ ).

\section{Sea-ice development and thickness}

According to 1-way ANOVAs, there were no significant differences between the different stages of seaice development (i.e. new ice, nilas, young ice and thin first-year ice) or ice thicknesses (i.e. $<10,10$ to 20 and $>20 \mathrm{~cm}$ ) for any of the variables presented in Table 1, except salinity and EPS:total chl a ratios. Salinity was significantly higher in sea ice $<10 \mathrm{~cm}$ as compared to sea ice from 10 to $20 \mathrm{~cm}$ thick (Tukey's HSD, p < 0.05). EPS:total chl a ratios were significantly higher in sea ice $>20 \mathrm{~cm}$ as compared to $<10 \mathrm{~cm}$ thick (Tukey's HSD, $\mathrm{p}<0.05)$ and in young ice as compared to nilas ice (Tukey's HSD, p < 0.05).

The 1-way ANOVAs also revealed that the enrichment indices of EPS, total chl $a$ and $\geq 5 \mu \mathrm{m}$ autotrophic protists were significantly higher in sea ice from 10 to $20 \mathrm{~cm}$ as compared to $<10 \mathrm{~cm}$ thick (Tukey's HSD, p < 0.05 ) and in young ice as compared to new ice (Tukey's HSD, $\mathrm{p}<0.05$ ). All other enrichment indices in Table 1 were not significantly different between the different stages of sea-ice development or between ice thicknesses.

Table 1. Physical, chemical and biological characteristics of newly formed sea ice and surface waters on the Mackenzie shelf and enrichment indices $\left(I_{\mathrm{S}}\right.$, see Eq. 1) for newly formed sea ice. Averages and ranges are given; $\mathrm{n}$ represents the number of data points for each variable. Note that enrichment values with $\mathrm{n} \leq 31$ are due to zero values in ice or surface waters. ${ }^{*}$ Significant enrichment $(p<0.001)$ in the sea ice compared to surface waters. Filamentous bacterial enrichment indices were not calculated since these cells were present in only 3 surface-water samples. EPS: exopolymeric substances; NA: not applicable

\begin{tabular}{|c|c|c|c|c|c|c|c|c|c|}
\hline \multirow{2}{*}{ Variable } & \multicolumn{3}{|c|}{ New sea-ice stations } & \multicolumn{3}{|c|}{ Surface waters } & \multicolumn{3}{|c|}{ Enrichment } \\
\hline & Average & Range & $\mathrm{n}$ & Average & Range & $\mathrm{n}$ & Average & Range & $\mathrm{n}$ \\
\hline Salinity & 8.3 & $4.6-22.2$ & 31 & 25.5 & $16.7-33.6$ & 32 & & NA & \\
\hline $\mathrm{NH}_{4}(\mu \mathrm{M})$ & 0.7 & $0.2-1.7$ & 29 & 1.0 & $0.1-3.5$ & 29 & $3.4^{*}$ & $0.6-21.7$ & 26 \\
\hline $\mathrm{NO}_{2}(\mu \mathrm{M})$ & 0.09 & $0.01-0.3$ & 17 & 0.2 & $0-0.4$ & 18 & $2.9^{*}$ & $0.2-14.7$ & 16 \\
\hline $\mathrm{NO}_{3}(\mu \mathrm{M})$ & 0.19 & $0.01-0.4$ & 28 & 0.3 & $0.02-1.5$ & 29 & $3.8^{*}$ & $0.4-21.2$ & 26 \\
\hline $\mathrm{Si}\left(\mathrm{OH}_{4}\right)(\mu \mathrm{M})$ & 2.5 & $0-11.7$ & 29 & 6.0 & $1.5-25.8$ & 31 & 1.5 & $0.1-7.4$ & 27 \\
\hline $\mathrm{PO}_{4}(\mu \mathrm{M})$ & 0.3 & $0-0.8$ & 20 & 0.8 & $0.03-2.9$ & 23 & 2.0 & $0.1-9.11$ & 14 \\
\hline $\mathrm{NO}_{3}: \mathrm{PO}_{4}$ (mol:mol) & 1.3 & $0.2-5.3$ & 16 & 1.0 & $0.03-5.6$ & 23 & & NA & \\
\hline $\operatorname{EPS}\left(\mu \mathrm{g}\right.$ xeq. $\left.\mathrm{l}^{-1}\right)$ & 295 & $27.5-1170$ & 30 & 126 & $11.8-868$ & 29 & $18.0^{*}$ & $1.5-61.8$ & 26 \\
\hline Total chl a $\left(\mu \mathrm{g} \mathrm{l}^{-1}\right)$ & 4.0 & $0.3-22.6$ & 32 & 0.8 & $0.2-4.9$ & 32 & $20.8^{*}$ & $0.9-111$ & 31 \\
\hline$>5 \mu \mathrm{m} \mathrm{chl} a\left(\mu \mathrm{gl}^{-1}\right)$ & 2.5 & $0.1-20.9$ & 32 & 0.4 & $0.03-3.8$ & 32 & $41.0^{*}$ & $0.9-185$ & 31 \\
\hline$>5 \mu \mathrm{m}:$ total chl a $(\%)$ & 52 & $17-96$ & 32 & 29 & $9.7-84$ & 32 & & NA & \\
\hline EPS:total chl a (g:g) & 138 & $12.4-544$ & 30 & 179 & $22.9-814$ & 29 & & NA & \\
\hline Bacteria $\left(10^{9}\right.$ cells $\left.\mathrm{l}^{-1}\right)$ & 1.1 & $0.2-2.0$ & 30 & 0.8 & $0.3-1.6$ & 32 & $5.1^{*}$ & $0.3-23.9$ & 29 \\
\hline Filamentous bacteria $\left(10^{6}\right.$ cells $\left.1^{-1}\right)$ & 13.7 & $0-67.0$ & 31 & 2.1 & $0-16.0$ & 32 & & NA & \\
\hline Hetero. protists $\left(10^{3}\right.$ cells $\left.l^{-1}\right)$ & 35.6 & $3.1-172$ & 32 & 16.3 & $0-108$ & 32 & $18.7^{*}$ & $1.0-93.7$ & 30 \\
\hline$\geq 5 \mu \mathrm{m}$ Auto. protists $\left(10^{3}\right.$ cells $\left.\mathrm{l}^{-1}\right)$ & 177 & $9.4-577$ & 32 & 20.5 & $0-97.4$ & 32 & $63.0^{*}$ & $1.7-409$ & 30 \\
\hline$<5 \mu \mathrm{m}$ Auto. protists $\left(10^{3}\right.$ cells $\left.1^{-1}\right)$ & 256 & $32.6-1114$ & 32 & 284 & $6.9-798$ & 32 & $4.6^{*}$ & $0.6-30.9$ & 31 \\
\hline
\end{tabular}


The majority $(75 \%)$ of sea-ice samples had low inorganic sediment content, whereas high sea-ice inorganic sediment content was found at only 4 stations located in shallow waters $(<100 \mathrm{~m})$ north of the mouth of the Mackenzie River estuary (Fig. 1, open circles). At this location, we measured the maximum hetero-

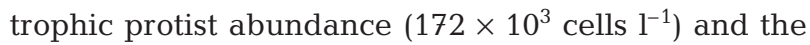

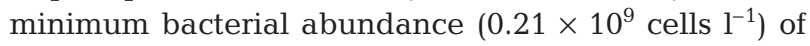
the entire sampling area. Average sea-ice bacterial abundances were significantly lower $(t$-test, $\mathrm{p}<0.01)$ and average sea-ice heterotrophic protist abundances were significantly higher $(t$-test, $\mathrm{p}<0.0001)$ at these 4 stations than in the rest of the sampling area.

\section{Sea-ice and surface-water assemblages}

All samples of newly formed sea ice contained both autotrophic and heterotrophic protists, as well as bacteria. Protist abundances may have been slightly underestimated, since fragile ciliates are not adequately quantified by our methods. In a concurrent study, M. Różańska (pers. comm.) found that ciliates constituted $<5 \%$ of total protist abundances. In the sea ice, $<5 \mu \mathrm{m}$ autotrophs were the most abundant protists (average: $256 \times 10^{3}$ cells $\mathrm{l}^{-1}$ ), followed by $<5 \mu \mathrm{m}$

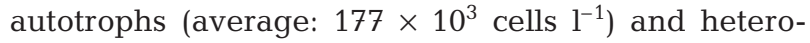
trophs (average: $36 \times 10^{3}$ cells $1^{-1}$; Table 1 ). Autotrophs $<5 \mu \mathrm{m}$, generally identified as autotrophic flagellates, contributed $58 \pm 21 \%$ of total autotrophic abundance, whereas $\geq 5 \mu \mathrm{m}$ autotrophs were generally identified as centric and pennate diatoms and contributed $42 \pm 21 \%$ of total autotrophic abundance. In surface waters, the abundance of $<5 \mu \mathrm{m}$ autotrophs was, on average, $>1$ order of magnitude higher than the abundance of $\geq 5 \mu \mathrm{m}$ autotrophs (Table 1 ).

The majority of bacteria in this study were freeliving single cells, although filamentous and diatomattached bacteria were also observed. Free-living, non-filamentous bacterial abundance in the sea ice and surface waters averaged $1.1 \pm 0.25 \times 10^{9}$ and $0.8 \pm$ $0.13 \times 10^{9}$ cells $1^{-1}$ (Table 1 ). Filamentous bacteria occurred in $81 \%$ of the sea-ice samples and in $45 \%$ of surface-water samples. In sea ice and surface waters, filament abundances were 2 orders of magnitude lower than free-living, non-filamentous bacterial abundances (Table 1). Filamentous bacteria were $<1 \mu \mathrm{m}$ in diameter, with an average filament length of $31.28 \pm 22.3 \mu \mathrm{m}$.

Total chl a concentrations ranged between 0.3 and $22 \mu \mathrm{g}^{-1}$ and between 0.2 and $4.9 \mu \mathrm{g} \mathrm{l}^{-1}$ in the sea ice and surface waters, respectively, whereas chl a concentrations of cells $>5 \mu \mathrm{m}$ ranged between 0.1 and $20 \mu \mathrm{g} \mathrm{l}^{-1}$ and between 0.03 and $3.8 \mu \mathrm{g} \mathrm{l}^{-1}$ in the sea ice and surface waters, respectively (Table 1). The percent chl $a>5 \mu \mathrm{m}$ in total chl a was, on average, $52 \pm 20$ and $29 \pm 19 \%$ in the sea ice and surface waters, respectively.

EPS concentrations ranged between 28 and $1170 \mu \mathrm{g}$ xeq. $\mathrm{l}^{-1}$ in the sea ice and between 12 and $868 \mu \mathrm{g}$ xeq. $\mathrm{l}^{-1}$ in the surface water, with an average EPS:total chl $a$ ratio of 138 and 179 in the sea ice and surface waters, respectively (Table 1). EPS concentrations were significantly related to chl a concentrations in the sea ice (total chl a: $\mathrm{r}=0.59, \mathrm{p}<0.001$; chl $a>5 \mu \mathrm{m}$ : $\mathrm{r}=0.62, \mathrm{p}<$ 0.001; Fig. 2A) and in surface waters (total chl a: $\mathrm{r}=$ $0.59, \mathrm{p}<0.001$; chl $a>5 \mu \mathrm{m}: \mathrm{r}=0.60, \mathrm{p}<0.001$; results
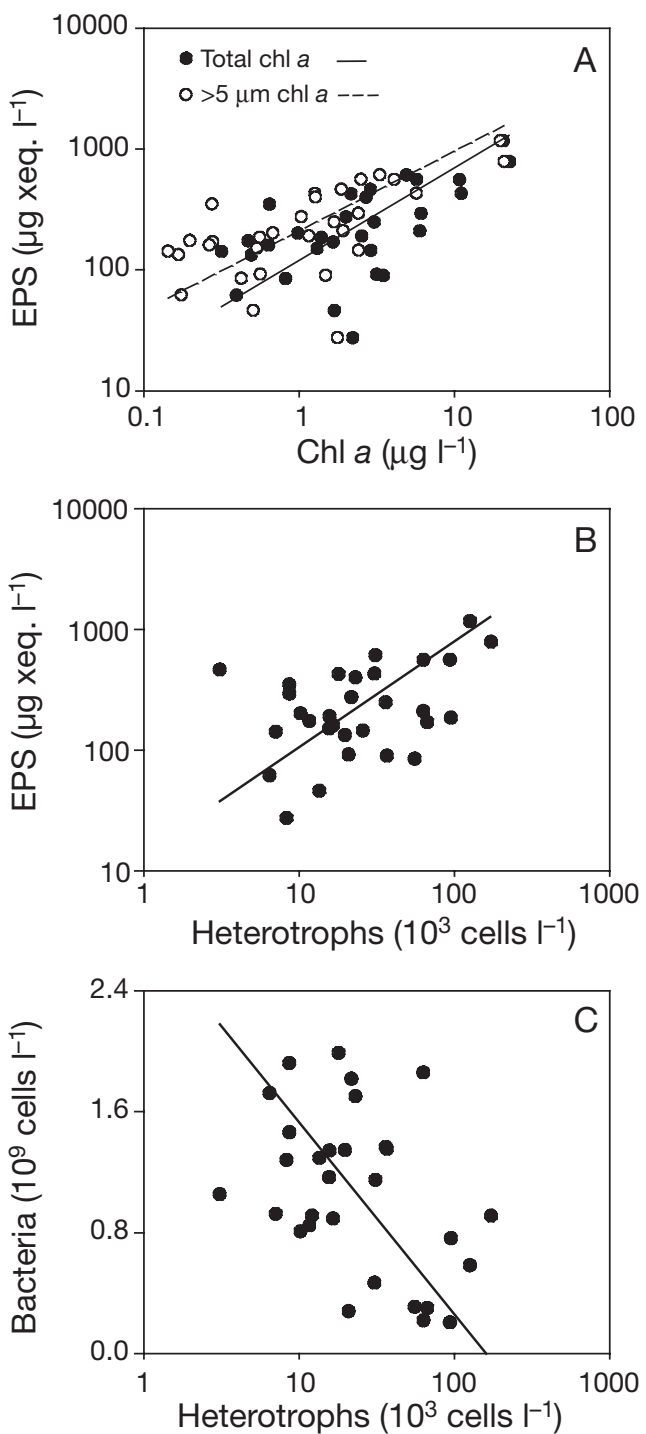

Fig. 2. Relationships between exopolymeric substances (EPS) concentrations and (A) chlorophyll $a$ ( $\mathrm{chl} a$; total and $>5 \mu \mathrm{m}$ ) concentrations and (B) heterotrophic protist abundances; and (C) relationship between bacterial and heterotrophic protist abundances for newly formed sea ice on the Mackenzie shelf. Note logarithmic scales for all variables except bacterial abundances 
not shown). In the sea ice, the slopes of the relationships between EPS concentrations and $>5 \mu \mathrm{m}$ and total chl a concentrations were not significantly different ( $p>0.05$ ). A weaker, yet significant, relationship was also observed between sea-ice EPS concentrations and the abundance of heterotrophic protists $(\mathrm{r}=0.41, \mathrm{p}<$ 0.05; Fig. 2B). Bacterial abundances were not significantly related to sea-ice EPS concentrations $(p=0.55$; results not shown), but were significantly related to heterotrophic protist abundances $(\mathrm{r}=-0.41, \mathrm{p}<0.05$; Fig. 2C).

\section{Enrichment}

Table 1 presents the enrichment indices for all variables measured during our study. All 3 forms of dissolved inorganic nitrogen (DIN; $\mathrm{NH}_{4}, \mathrm{NO}_{2}, \mathrm{NO}_{3}$ ) were significantly enriched in the newly formed sea ice, with average $I_{\mathrm{S}}$ values of 3.4, 2.9 and 3.8 for $\mathrm{NH}_{4}, \mathrm{NO}_{2}$ and $\mathrm{NO}_{3}$, respectively (Table 1). $\mathrm{Si}(\mathrm{OH})_{4}$ and $\mathrm{PO}_{4}$ enrichment indices were not significantly different from 1 (Wilcoxon's signed-ranks, $\mathrm{Si}(\mathrm{OH})_{4}: \mathrm{p}=0.14$;
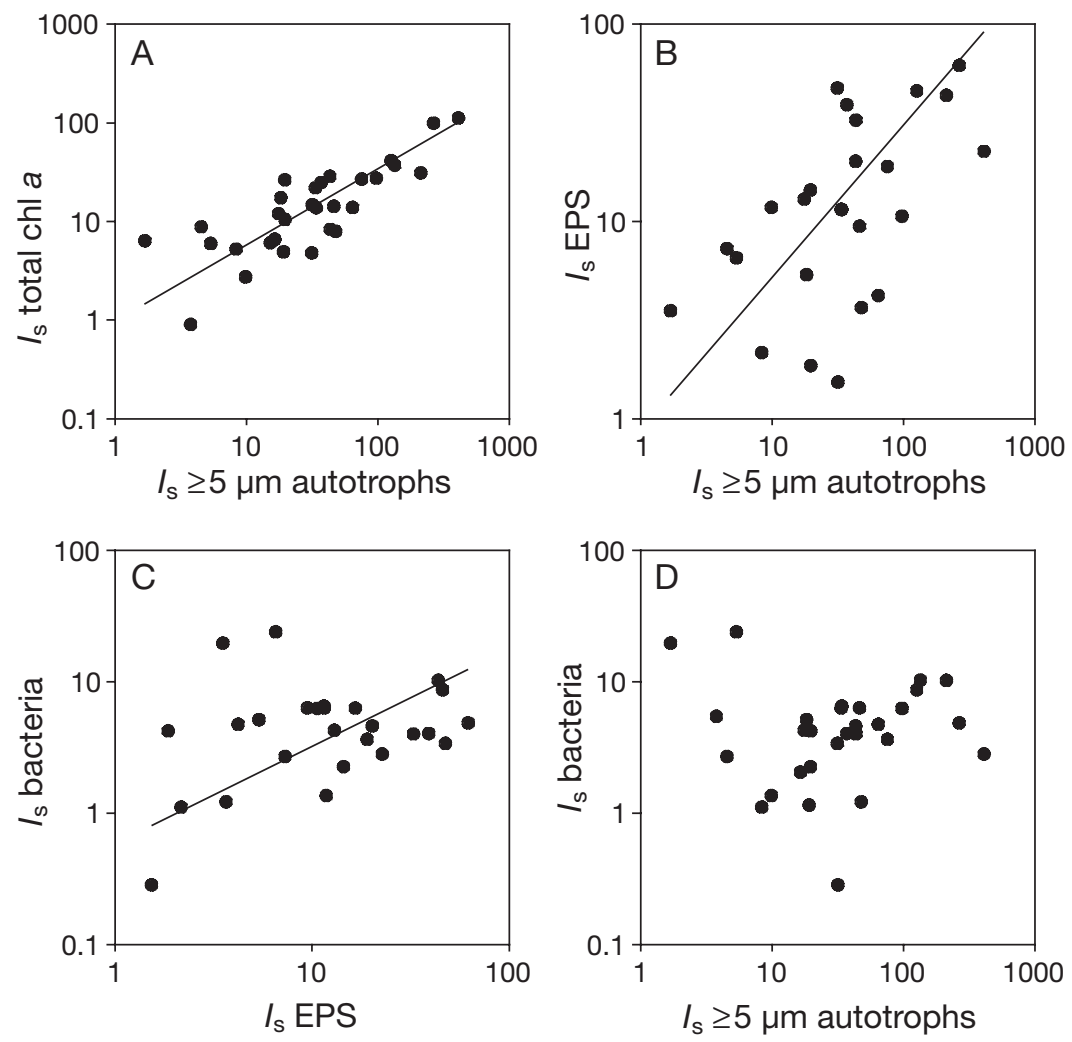

Fig. 3. Relationships between the enrichment indices $\left(I_{\mathrm{S}}\right)$ of $(\mathrm{A})$ chlorophyll $a$ (chl a) and $\geq 5 \mu \mathrm{m}$ autotrophs, (B) exopolymeric substances (EPS) and $\geq 5 \mu \mathrm{m}$ autotrophs, (C) bacteria and EPS and (D) bacteria and $\geq 5 \mu \mathrm{m}$ autotrophs for newly formed sea ice on the Mackenzie shelf. Open circles are not included in the regression analyses. Note logarithmic scales for all variables
$\mathrm{PO}_{4}: \mathrm{p}=0.33$ ), with average $I_{\mathrm{S}}$ values of 1.5 and 2.0 , respectively (Table 1).

Total and $>5 \mu \mathrm{m}$ chl $a$, free-living bacteria and heterotrophic and autotrophic protists were significantly enriched in the newly formed sea ice (Wilcoxon's signed-ranks, p < 0.001; Table 1). Enrichment indices for filamentous bacteria could not be calculated due to the absence of filamentous bacteria in numerous surface-water samples. Amongst the protist groups, autotrophic protists $\geq 5 \mu \mathrm{m}$ had the highest average $I_{\mathrm{S}}(63)$, whereas heterotrophic protists and $<5 \mu \mathrm{m}$ autotrophs had average $I_{\mathrm{S}}$ values of 18.7 and 4.7 , respectively (Table 1). The high $I_{\mathrm{S}}$ values for $\geq 5 \mu \mathrm{m}$ autotrophs are consistent with the higher average $I_{\mathrm{S}}$ for $>5 \mu \mathrm{m}$ chl a (41) as compared to total chl a (21; Table 1). The enrichment indices of total chl a were significantly related to the enrichment indices of $\geq 5 \mu \mathrm{m}$ autotrophs ( $\mathrm{r}=0.75$, p $<0.001$; Fig. 3A), but were not significantly related to the enrichment indices of the $<5 \mu \mathrm{m}$ autotrophic protists ( $p=0.38$; results not shown).

EPS were enriched in the newly formed sea-ice samples, with an average $I_{\mathrm{S}}$ of 18.0 (range 1.5 to 62 ; Table 1). EPS enrichment indices were significantly related to the enrichment indices of $\geq 5 \mu \mathrm{m}$ autotrophs $(\mathrm{r}=0.48, \mathrm{p}<0.05$; Fig. 3B). Enrichment indices for freeliving bacteria were also significantly related to EPS enrichment indices ( $\mathrm{r}=$ 0.57, p < 0.01; Fig. 3C), but were not significantly related to the enrichment indices of $\geq 5 \mu \mathrm{m}$ autotrophs ( $p=0.31$; Fig. 3D).

\section{Ammonium regeneration rates}

Summary results from the $\mathrm{NH}_{4}$ regeneration experiments are presented in Table 2. During the $24 \mathrm{~h}$ incubation, $\mathrm{NH}_{4}$ concentrations increased in 5 of the 7 experiments, whereas $\mathrm{NH}_{4}$ concentrations decreased in the other 2 experiments. The average net regeneration rate estimated from increases in $\mathrm{NH}_{4}$ concentrations was $0.48 \mu \mathrm{M}$ $\mathrm{d}^{-1}$, with values ranging between 0.12 and $1.2 \mu \mathrm{M} \mathrm{d}^{-1}$. The average net consumption rate of $\mathrm{NH}_{4}$ was $0.25 \mu \mathrm{M} \mathrm{d}^{-1}$, with values of 0.16 and $0.34 \mu \mathrm{M} \mathrm{d}^{-1}$ (Table 2).

In the 5 experiments where $\mathrm{NH}_{4}$ concentrations increased over the $24 \mathrm{~h}$ experimental period, average $\mathrm{NO}_{3}$ and $\mathrm{Si}(\mathrm{OH})_{4}$ concentrations decreased at an average rate of $0.10 \pm 0.08$ and 
Table 2. Summary of $\mathrm{NH}_{4}$ regeneration experiments. Concentrations of nutrients and total chl a and bacterial and protist abundances provided are those measured at the beginning of each experiment. Nutrient regeneration and consumption rates are estimated from changes in nutrient concentration over the duration of the experiments $(24 \mathrm{~h})$. Consumption rates are indicated by a minus sign. All regression coefficients (i.e. the rates) are significantly different from zero ( $p<0.05)$. ND: not determined; $r$ or $\mathrm{c}$ : regeneration or consumption

\begin{tabular}{|c|c|c|c|c|c|c|c|c|c|c|c|}
\hline \multirow[t]{2}{*}{ Date } & \multirow{2}{*}{$\begin{array}{l}\text { Ice } \\
\text { type }\end{array}$} & \multirow{2}{*}{$\begin{array}{c}\text { Ice } \\
\text { thickness } \\
(\mathrm{cm})\end{array}$} & \multicolumn{3}{|c|}{ Nutrient conc. } & \multirow{2}{*}{$\begin{array}{c}\text { Total } \\
\text { chl } a \\
\left(\mu \mathrm{g} \mathrm{l}^{-1}\right)\end{array}$} & \multicolumn{2}{|c|}{ Heterotrophic } & \multicolumn{3}{|c|}{ Nutrient $\mathrm{r}$ or $\mathrm{c}$ rates } \\
\hline & & & $\begin{array}{l}\mathrm{NH}_{4} \\
(\mu \mathrm{M})\end{array}$ & $\begin{array}{l}\mathrm{NO}_{3} \\
(\mu \mathrm{M})\end{array}$ & $\begin{array}{c}\mathrm{Si}\left(\mathrm{OH}_{4}\right) \\
(\mu \mathrm{M})\end{array}$ & & 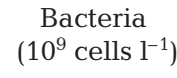 & $\begin{array}{c}\text { Protists } \\
\left(10^{3} \text { cells } 1^{-1}\right)\end{array}$ & $\begin{array}{c}\mathrm{NH}_{4} \\
\left(\mu \mathrm{M} \mathrm{d}^{-1}\right)\end{array}$ & $\begin{array}{c}\mathrm{NO}_{3} \\
\left(\mu \mathrm{M} \mathrm{d}^{-1}\right)\end{array}$ & $\begin{array}{r}\mathrm{Si}\left(\mathrm{OH}_{4}\right) \\
\left(\mu \mathrm{M} \mathrm{d}^{-1}\right)\end{array}$ \\
\hline 30 Sep & Nilas & 0.1 & 0.83 & 0.20 & 9.4 & 10.7 & 0.22 & 63 & 1.2 & ND & ND \\
\hline 30 Sep & New & 3.0 & 1.1 & ND & ND & 5.7 & 0.21 & 93 & 0.42 & ND & ND \\
\hline 2 Oct & Nilas & 0.1 & 0.60 & 0.17 & 2.7 & 1.4 & 0.76 & 95 & 0.25 & -0.16 & -1.7 \\
\hline 3 Oct & Nilas & 2.5 & 0.62 & 0.06 & 0.12 & 0.82 & 0.31 & 55 & -0.16 & -0.01 & -0.02 \\
\hline 8 Oct & New & 2.0 & 0.45 & 0.07 & 1.2 & 0.47 & 0.85 & 12 & 0.44 & -0.04 & -1.2 \\
\hline 8 Oct & Nilas & 2.0 & 0.33 & 0.01 & 1.08 & 0.39 & 1.7 & 6.4 & -0.34 & 0.10 & -0.16 \\
\hline 12 Oct & New & 0.5 & 0.64 & ND & ND & 2.9 & ND & 26 & 0.12 & ND & ND \\
\hline
\end{tabular}
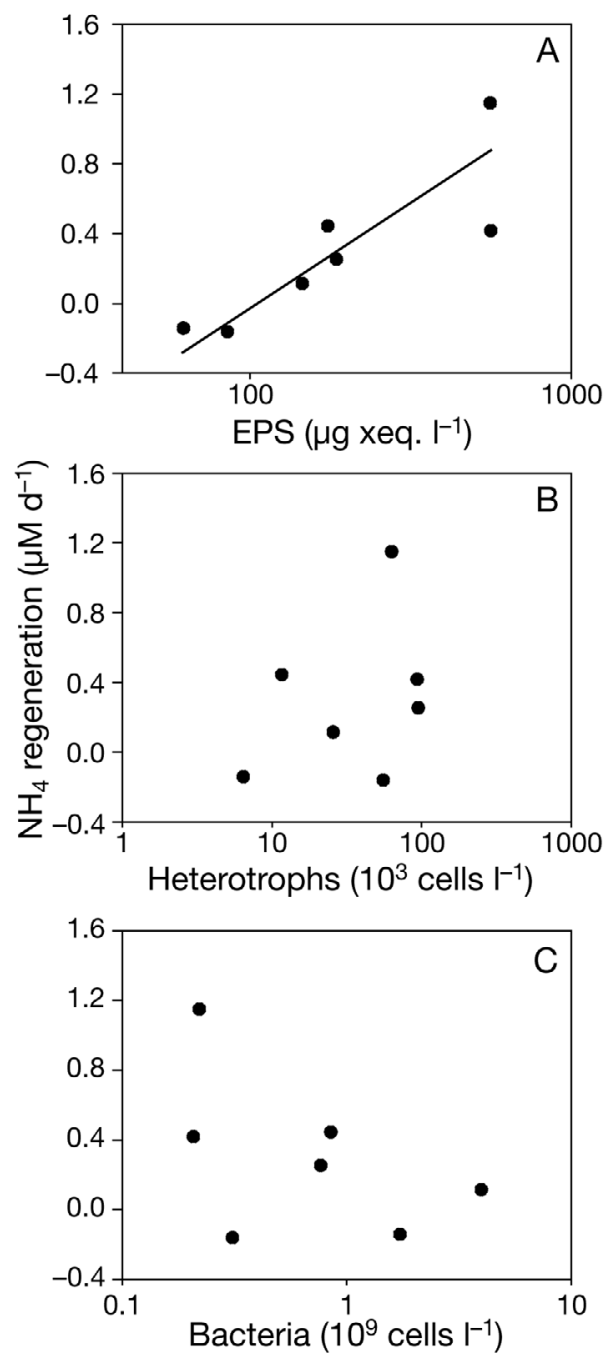

Fig. 4. Relationships between net $\mathrm{NH}_{4}$ regeneration rates and (A) exopolymeric substances (EPS) concentrations, (B) heterotrophic protist abundance and $(\mathrm{C})$ bacterial abundance in newly formed sea ice on the Mackenzie shelf. Note logarithmic scales for $x$-axes
$1.4 \pm 0.4 \mu \mathrm{M} \mathrm{d}^{-1}$, respectively. In the first experiment where $\mathrm{NH}_{4}$ concentrations decreased, $\mathrm{NO}_{3}$ and $\mathrm{Si}(\mathrm{OH})_{4}$ decreased at a rate of 0.01 and $0.02 \mu \mathrm{M} \mathrm{d}^{-1}$, respectively ( 3 October; Table 2 ). In the second experiment, $\mathrm{NO}_{3}$ increased at a rate of $0.1 \mu \mathrm{M} \mathrm{d}^{-1}$, whereas $\mathrm{Si}(\mathrm{OH})_{4}$ decreased at a rate of $0.16 \mu \mathrm{M} \mathrm{d}^{-1}$ (8 October; Table 2). The concentration of chl a and abundance of bacteria and heterotrophic protists ( $t$-test, $\mathrm{p}=0.60$ to 0.80 ) did not change significantly over the $24 \mathrm{~h}$ duration of any experiment. Ammonium regeneration rates were significantly related with EPS concentrations ( $\mathrm{r}=$ 0.87, p < 0.05; Fig. 4A), while there was no clear relationship between $\mathrm{NH}_{4}$ regeneration rates and the abundances of sea-ice heterotrophic protists $(p=0.34$; Fig. 4B) or bacteria ( $p=0.26$; Fig. 4C).

Fig. 5 presents relationships amongst biological variables from parallel sea-ice samples during the period when the dark incubation experiments were conducted (30 September to 18 October). A significant negative relationship between sea-ice $\mathrm{NH}_{4}$ concentrations and bacterial abundances was observed ( $\mathrm{r}=$ -0.68 , p < 0.05; Fig. 5A), whereas $\mathrm{NH}_{4}$ concentrations were not significantly related to heterotrophic protist abundances ( $p=0.23$; Fig. 5B), but sea-ice EPS concentrations were significantly related to heterotrophic protist abundances ( $r=0.77, \mathrm{p}<0.01$; Fig. 5C).

\section{DISCUSSION}

This study allowed for the in situ collection of very young sea ice. Sea ice can grow up to a thickness of ca. $10 \mathrm{~cm}$ within a single day (Eicken 2003), indicating that the majority of our samples were only hours or days old. Therefore, we present results on microbial assemblages and the biological activity of sea-ice communities at very early stages of sea-ice formation on an Arctic continental shelf and slope. 

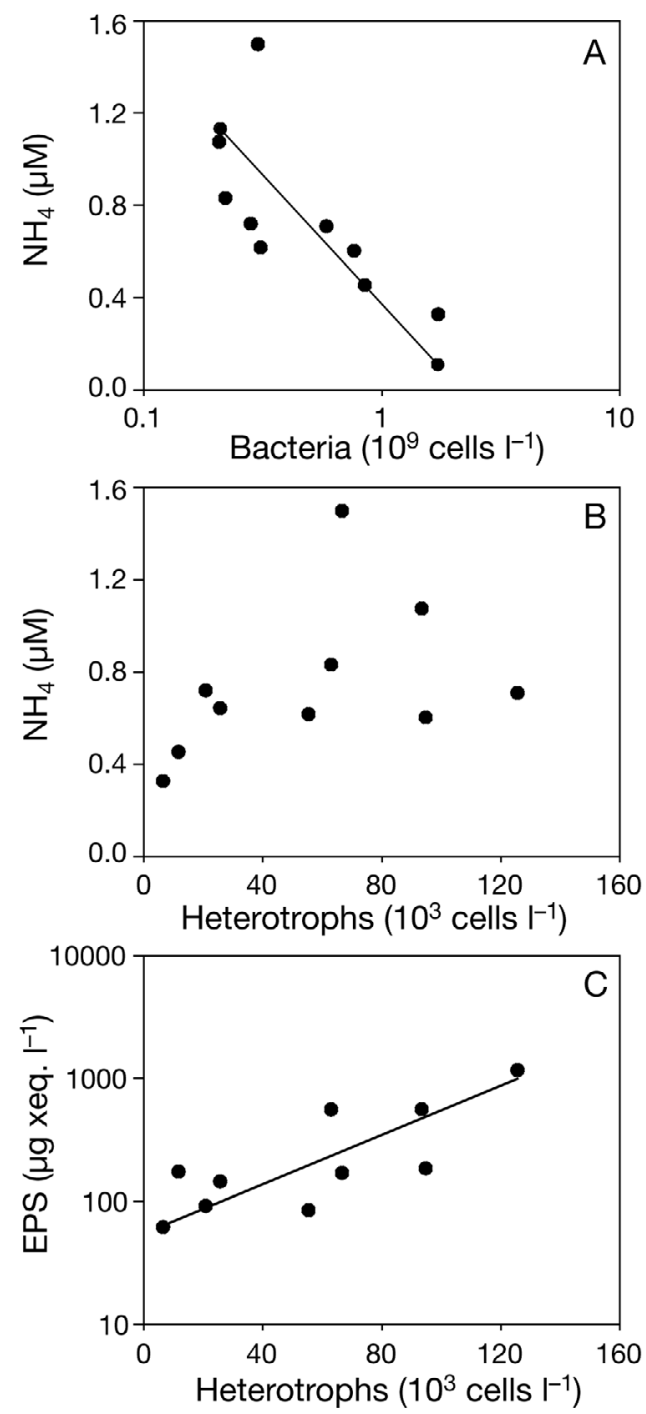

Fig. 5. Relationships between $\mathrm{NH}_{4}$ concentrations and (A) bacterial abundance and (B) heterotrophic protist abundance and between (C) exopolymeric substance (EPS) concentrations and heterotrophic protist abundances in newly formed sea ice sampled in parallel to the dark incubations. Note logarithmic scale for bacteria and EPS $(\mathrm{A}, \mathrm{C})$

Our newly formed sea-ice samples were collected over a large geographical area, with the sea ice differing in thickness and stage of development. However, these variations in the newly formed sea ice had no effect on measured variables except for $\geq 5 \mu \mathrm{m}$ autotrophs and their related variables (i.e. EPS and chl a). The sediment-laden Mackenzie River outflow appeared to influence both bacterial and heterotrophic protist abundances within the sea ice, but only within a localised area (Fig. 1). We thus conclude that the results of this study are generally applicable to the extensive Mackenzie shelf and slope region, and possibly other Arctic shelves.

\section{Sea-ice assemblages}

All samples of newly formed sea ice, even those $<1 \mathrm{~cm}$ thick, contained similar multi-trophic level communities comparable to those observed in a previous study of newly formed sea ice in the Greenland Sea (Gradinger \& Ikävalko 1998). These communities generally consist of free-living bacteria, phototrophic flagellates, diatoms and other autotrophic and heterotrophic protists. In our study, autotrophs $<5 \mu \mathrm{m}$ in diameter were the most abundant protists (Table 1), whereas diatoms represented the largest cells within the sea ice. There was no evidence of large flagellates (e.g. $>70 \mu \mathrm{m}$ ) or meiofauna (e.g. nematodes), which are conspicuous components of multi- and first-year Arctic sea ice (Nozais et al. 2001, Michel et al. 2002).

The majority $(>80 \%)$ of our sea-ice samples also contained filamentous bacteria, which have not been previously reported in newly formed sea ice of the Arctic, but were observed in newly formed pack ice of Antarctica (Zdanowski 1988). Filamentous bacteria appear to be a temporary component of sea-ice assemblages on the Mackenzie shelf, since they were not observed in any sea-ice samples collected only a few months later (February to June) in the same region (Riedel et al. 2006). For the remainder of this discussion, bacteria will refer to non-filamentous bacteria only.

Concentrations of sea-ice bacteria were lowest at the stations in closest proximity to the Mackenzie River (Fig. 1, open circles), despite these stations having the highest concentrations of inorganic sediments in the sea ice and average bacterial concentrations (average of 4 stations: $0.8 \times 10^{9}$ cells $\mathrm{l}^{-1}$ ) in the surface water (Table 1). This suggests that inorganic sediments, efficiently scavenged by frazil in the Arctic (Reimnitz et al. 1993), are not a major pathway by which bacteria entered the sea ice. In our samples, bacteria were not observed to be attached to inorganic sediments, although this attachment may have been disturbed during sample preparation. Bacteria may also have been grazed after their incorporation into the sea ice at the stations in closest proximity to the Mackenzie River, since lowest bacterial concentrations were also coupled with highest concentrations of sea-ice heterotrophic protists. The area of the Beaufort shelf near the mouth of the Mackenzie River is characterised by high heterotrophic activity (Parsons et al. 1988), and our study suggests that active heterotrophy may also be occurring within sea ice which forms in this area.

\section{Sea-ice EPS}

This study documents the wide-scale presence of EPS in newly formed sea ice on an Arctic shelf 
(Table 1). During the spring and summer, diatoms are primarily responsible for EPS production in first-year sea ice (Krembs \& Engel 2001, Meiners et al. 2003, Riedel et al. 2006). The similarities in slopes of the relationships between EPS and total chl $a$ and EPS and $>5 \mathrm{chl}$ a concentrations (Fig. 2A) point to a tight linkage between EPS and large autotrophic producers in the sea ice during this study. This is also supported by the significant relationship between the enrichment of EPS and $\geq 5 \mu \mathrm{m}$ autotrophs (Fig. 3B).

The relationship between EPS and $\geq 5 \mu \mathrm{m}$ autotroph enrichment indices (Fig. 3B) and the fact that EPS occurred in all sea-ice samples only hours old suggest that EPS were incorporated into the sea ice in association with phytoplankton and/or benthic algal cells scavenged by rising frazil ice crystals. Relatively high concentrations of EPS (i.e. average $>300 \mu \mathrm{g}$ xeq. $\mathrm{l}^{-1}$ ) were observed in the thinnest sea ice (i.e. $<1 \mathrm{~cm}$ thick), suggesting that algal cells with their attached EPS were being incorporated at the time of sea-ice formation. In the fall, phytoplankton cells are likely to be nutrient limited, as indicated by the low $\mathrm{NO}_{3}: \mathrm{PO}_{4}$ during our study (Table 1), and as observed in other Arctic environments (e.g. Cota et al. 1996, Lewis et al. 1996). Therefore phytoplankton may have been producing elevated amounts of EPS due to nutrient limitation (Magaletti et al. 2004), which could become incorporated in the newly formed sea ice.

Alternatively or additionally, EPS could be produced by algal cells after they are entrapped in the sea ice, as indicated by the significantly higher EPS:total chl a ratios in young versus nilas sea ice and in $>20 \mathrm{~cm}$ versus $<10 \mathrm{~cm}$ thick sea ice (ANOVAs, $\mathrm{p}<0.05$ ). This suggests that EPS continue to accumulate within the sea ice during its growth, even after scavenging by frazil ends, at a sea-ice thickness of ca. $5 \mathrm{~cm}$ (Weeks \& Ackley 1982). We suggest that entrapped diatoms continue to actively produce EPS within the newly formed sea ice. EPS may be produced in response to altered nutrient conditions (Magaletti et al. 2004) or for cryoprotection against high salinities or growing ice crystals, thereby enhancing the survival of cells within the newly formed sea ice (Krembs et al. 2002). We thus conclude that EPS are incorporated with scavenged algal cells and continue to be actively produced by algal cells within newly formed sea ice of the Arctic.

Sampling conducted in March 2004 in Franklin Bay (Fig. 1) found EPS concentrations at the sea-ice bottom to be, on average, $185 \mu \mathrm{g}$ xeq. $\mathrm{l}^{-1}$ (range 91 to $388 \mu \mathrm{g}$ xeq. $\mathrm{l}^{-1}$; Riedel et al. 2006), less than one-third of the new sea-ice EPS measured at the same site at the beginning of November $\left(600 \mu \mathrm{g}\right.$ xeq. $\left.\mathrm{l}^{-1}\right)$. This may indicate that EPS do not accumulate in sea ice throughout the entire winter period, but, instead, EPS appear to be lost from, or utilised within, the sea ice after the fall period included in this study. EPS were found to be retained within the sea ice during the spring melt on the Mackenzie shelf (Riedel et al. 2006); therefore, it is unlikely that EPS would be released from the sea ice during the winter period. EPS concentrations in our study did not vary significantly between the different sea-ice thicknesses (i.e. $<10,10$ to $20,>20 \mathrm{~cm}$; ANOVA, $p=0.26$ ), suggesting that EPS were not lost from the sea ice due to continued brine drainage during sea-ice formation (Eicken 2003). We thus hypothesise that, during the winter period, sea-ice EPS may be broken down or change chemically such that these EPS would not be detected by our analytical methods, or that EPS may be utilised as a carbon source for bacteria or other heterotrophs present in the sea ice, as reported for similar exopolymers in the water column (Sherr 1988, Tranvik et al. 1993).

\section{Enrichment and selectivity in newly formed sea ice}

The newly formed sea ice was significantly enriched in nitrogenous nutrients, chl $a$, EPS, bacteria and protists. The enrichment of EPS has been documented in only 1 other sea-ice study. An enrichment value of 5.6 was obtained from a single sample of nilas sea ice, $11 \mathrm{~cm}$ thick, from the Antarctic (Meiners et al. 2004), thus falling at the lower range of EPS enrichment indices observed in our study (Table 1). EPS enrichment in the sea ice of the Mackenzie shelf appeared to be associated with the incorporation of algae and bacteria, as discussed below.

Among the microorganisms, enrichment indices were lowest for bacteria and $<5 \mu \mathrm{m}$ autotrophs and highest for $\geq 5 \mu \mathrm{m}$ autotrophs (Table 1 ). The same pattern of enrichment was observed by Gradinger \& Ikävalko (1998) in a study of newly formed drift ice near Greenland. It thus appears that during sea-ice formation in the Arctic there is consistent selectivity for larger autotrophic cells. Our results suggest that both cell size and cellassociated EPS are key factors influencing the selection of large autotrophs during sea-ice formation.

Assuming that the effect of cell size on enrichment is consistent for $\geq 5 \mu \mathrm{m}$ autotrophic and heterotrophic protists, we calculated the expected enrichment of $\geq 5 \mu \mathrm{m}$ autotrophic protists based on the size:enrichment ratio of the heterotrophic protists (i.e. $I_{\mathrm{S}}$ autotrophs $=$ average autotroph size $\times$ average heterotroph size $/ I_{\mathrm{S}}$ heterotrophs). Based on this ratio, we would expect an average enrichment index of 42 , instead of the observed enrichment index of 62 , for the autotrophic protists $\geq 5 \mu \mathrm{m}$. We surmise that the higher enrichment index observed is caused by the association of EPS with autotrophic cells (Fig. 2A). Algal cells associated with even small amounts of EPS would have 
sticky surfaces that could increase their probability of attaching to rising frazil ice crystals. Estimates of exopolymer stickiness (e.g. Dam \& Drapeau 1995) have been found to be 2 to 4 orders of magnitude higher than the stickiness of other particles (Passow 2002b).

Average bacterial enrichment indices in newly formed sea ice on the Mackenzie shelf (average $I_{\mathrm{S}}=$ 5.5) closely matched those from pancake and nilas sea ice $<22 \mathrm{~cm}$ thick, sampled near Greenland (average $I_{\mathrm{S}}=7$; Gradinger \& Ikävalko 1998). Bacterial enrichment has been suggested to be an indirect result of attachment to larger cells, in particular algal cells, instead of direct scavenging by rising frazil ice (Grossmann \& Dieckmann 1994, Weissenberger \& Grossmann 1998). However, the attachment of bacteria to diatoms was observed in only $12.5 \%$ of our newly formed sea-ice samples, and we did not observe a direct relationship between bacterial enrichment and the enrichment of $\geq 5 \mu \mathrm{m}$ autotrophs (Fig. 3D). It is possible that $\geq 5 \mu \mathrm{m}$ autotrophs indirectly enhanced the enrichment of bacteria by the production of EPS, since bacterial enrichment indices were significantly related to EPS enrichment indices (Fig. 3C). The attachment of bacteria to exopolymers has been directly observed in pelagic (Passow \& Alldredge 1994) and benthic (Underwood et al. 1995) environments.

\section{Nutrient regeneration}

The enrichment of nitrogenous nutrients and lack of enrichment for $\mathrm{PO}_{4}$ or $\mathrm{Si}(\mathrm{OH})_{4}$, are consistent with the results of Gradinger \& Ikävalko (1998), who suggested that the enrichment of DIN was a consequence of heterotrophic regeneration within the sea ice. Dark incubation experiments carried out during this study showed that heterotrophic biological activity could contribute, on average, $67 \%$ of $\mathrm{NH}_{4}$ concentrations in the newly formed sea ice on the Mackenzie shelf. Ammonium regeneration rates have not previously been determined for newly formed sea ice in the Arctic. Our estimated net $\mathrm{NH}_{4}$ regeneration rates $(0.1$ to 1.2 $\mu \mathrm{M} \mathrm{d}^{-1}$ ) fall within the same range as $\mathrm{NH}_{4}$ regeneration rates measured from open water in coastal zone areas using ${ }^{15} \mathrm{~N}$ isotopic methods (e.g. 0.17 to $1.30 \mu \mathrm{M}$ $\mathrm{d}^{-1}$; Maguer et al. 1999, Molina et al. 2005). The newly formed sea ice appears to be an environment of primarily regenerated nutrients given that $\mathrm{NO}_{3}: \mathrm{PO}_{4}$ ratios were very low (i.e. $<2$ ) and $\mathrm{NH}_{4}$ was the dominant form of DIN (Table 1). This indicates that heterotrophic regenerative processes are an important component of nutrient cycling in newly formed sea ice of the Arctic. It is likely that regeneration within first-year sea ice continues during the winter period. Reduced metabolic activity of autotrophic cells during the dark winter
(Zhang et al. 1998), together with continued heterotrophic regeneration, could result in the accumulation of $\mathrm{NH}_{4}$, possibly supporting the onset of the spring seaice algal bloom (Conover et al. 1999).

The regeneration of $\mathrm{NH}_{4}$ and dark consumption of $\mathrm{NO}_{3}$ and $\mathrm{Si}(\mathrm{OH})_{4}$ were coupled, with no measurable regeneration occurring at low consumption rates (Table 2). It was apparent that the relatively high concentrations of sea-ice $\mathrm{NH}_{4}$ (Table 1) did not inhibit $\mathrm{NO}_{3}$ consumption by the sea-ice algae. Ammonium concentrations $<1 \mu \mathrm{M}$ have been observed to inhibit $\mathrm{NO}_{3}$ uptake and/or assimilation within the water column (Wheeler \& Kokkinakis 1990) and possibly in sea ice (Priscu \& Sullivan 1998). Dark consumption of $\mathrm{NO}_{3}$ in our study can be attributed, at least in part, to diatom cells specifically, since diatoms are the only group that would also be taking up $\mathrm{Si}(\mathrm{OH})_{4}$ for growth. Dark consumption of $\mathrm{NO}_{3}$ by sea-ice algae has been previously reported for bottom sea ice of McMurdo Sound, Antarctica, with dark consumption being $<50 \%$ of light-mediated $\mathrm{NO}_{3}$ consumption (Priscu et al. 1991). Dark $\mathrm{NO}_{3}$ consumption has been suggested to indicate nitrogen limitation for phytoplankton (Kanda et al. 1989). However, the nutrient status of the sea-ice algae in this study is not known.

Dark consumption of $\mathrm{NH}_{4}$ by the sea-ice algae was likely also occurring during our experiments, since $\mathrm{NH}_{4}$ is a preferred nitrogen source for sea-ice algae (Harrison et al. 1990). Concurrent dark consumption of both $\mathrm{NO}_{3}$ and $\mathrm{NH}_{4}$ has been shown to occur in bottom sea-ice of Antarctica (Priscu et al. 1991). In addition, bacterial consumption of $\mathrm{NH}_{4}$ may have been occurring during our experiments, as indicated by the significant negative relationship between $\mathrm{NH}_{4}$ concentrations and bacterial abundances in the sea ice (Fig. 5A). Significant consumption of $\mathrm{NH}_{4}$ by bacteria has been previously suggested for Arctic first-year seaice communities in Barrow Strait (Harrison et al. 1990). Therefore, our $\mathrm{NH}_{4}$ regeneration rates are potentially underestimated, due to dark $\mathrm{NH}_{4}$ consumption by both algae and heterotrophic bacteria.

We did not observe a clear relationship between $\mathrm{NH}_{4}$ regeneration and heterotrophic protists in the sea ice (Figs. 4B \& 5B). Heterotrophic bacteria can also regenerate $\mathrm{NH}_{4}$ (Glibert 1993), although no significant relationship between $\mathrm{NH}_{4}$ regeneration and bacteria was observed during our study (Figs. 4C \& 5A). Ammonium regeneration rates were only significantly related to sea-ice EPS concentrations (Fig. 4A), which were shown to enhance $\mathrm{NH}_{4}$ regeneration rates. EPS appear to be directly involved in the process of sea-ice $\mathrm{NH}_{4}$ regeneration, since there was no direct relationship between EPS and $\mathrm{NH}_{4}$ concentrations in the sea ice $(p=0.96)$. We suggest that EPS stimulate grazing by heterotrophic protists (Figs. 2B \& 5C), thereby enhancing $\mathrm{NH}_{4}$ regeneration in sea ice. EPS may be specifi- 
cally selected as a carbon source (Sherr 1988, Tranvik et al. 1993) or EPS may facilitate the consumption of bacteria by heterotrophic protists.

Meiners et al. (2004) observed that $100 \%$ of EPS in Antarctic pack ice were colonised by bacteria, and Passow \& Alldredge (1994) observed a similar level of colonisation for TEP in the water column. Bacteria attached to EPS may be more easily grazed by heterotrophic protists than free-living bacteria, since the attached bacteria are part of a larger particle. Bacteria EPS interactions could therefore support increased grazing rates, explaining the observed negative relationship between bacteria and heterotrophic protists (Fig. 2C), resulting in enhanced $\mathrm{NH}_{4}$ regeneration rates in the newly formed sea ice on Arctic shelves.

\section{CONCLUSIONS}

All groups of microorganisms, including bacteria, were significantly enriched in the newly formed sea ice on the Mackenzie shelf and slope. There was a clear selection for large autotrophic cells, likely due to cell size and the presence of EPS, which greatly enhances the stickiness of cell surfaces. These larger sized autotrophic cells also appeared to be responsible for the incorporation of bacteria into the newly formed sea ice, with EPS potentially mediating these interactions.

Microorganisms in newly formed sea ice are active, taking up $\mathrm{NO}_{3}$ and $\mathrm{Si}(\mathrm{OH})_{4}$ and producing $\mathrm{NH}_{4}$. Heterotrophic regeneration increased the concentration of $\mathrm{NH}_{4}$ within the newly formed sea ice, whereas $\mathrm{Si}(\mathrm{OH})_{4}$ and $\mathrm{PO}_{4}$ were not significantly enriched in newly formed sea ice as compared to the surface water. Our experiments showed that $\mathrm{NH}_{4}$ regeneration could contribute, on average, $67 \%$ of the ambient $\mathrm{NH}_{4}$ concentrations within the newly formed sea ice. Given that (1) there was significant $\mathrm{NH}_{4}$ regeneration, (2) $\mathrm{NH}_{4}$ was the dominant source of DIN and (3) low $\mathrm{NO}_{3}: \mathrm{PO}_{4}$ ratios were observed in sea ice, we conclude that the newly formed sea ice is a regenerative environment and that heterotrophic regeneration constitutes an important component of nutrient cycling in newly formed sea ice of the Arctic. Our results indicate that EPS may be an important substrate stimulating heterotrophic activity in newly formed sea ice.

Acknowledgements. This project was supported by grants from the Natural Sciences and Engineering Research Council (NSERC) of Canada (Research Network grant to C.M. and M.G.; Individual and Northern Research Supplement Discovery grants to M.G.) and from the Department of Fisheries and Oceans (DFO) Academic Science Subvention Program to M.G. and C.M., and from the Science Strategic Fund to C.M. Partial operating funds for the CCGS 'Amundsen' were pro- vided by the International Joint Ventures Fund of the Canada Foundation for Innovation and the Fonds québécois de la recherche sur la nature et les technologies (FQRNT). A.R. received post-graduate scholarships from NSERC, UQAR, the Fondation de l'UQAR (bourse Estelle-Laberge) and the Institut des sciences de la mer de Rimouski (ISMER), and financial support from Indian and Northern Affairs Canada for fieldwork. We sincerely thank the officers and crew of the CCGS 'Amundsen' for their support of this research expedition; $M$. Poulin for assisting in the field and laboratory; and J. É. Tremblay and K. Simpson for conducting the nutrient analyses. This is a contribution to the research programs of the Canadian Arctic Shelf Exchange Study (CASES), the Freshwater Institute (Fisheries and Oceans Canada), ISMER and QuébecOcéan.

\section{LITERATURE CITED}

Arrigo KR, Dieckmann G, Gosselin M, Robinson DH, Fritsen $\mathrm{CH}$, Sullivan CW (1995) High resolution study of the platelet ice ecosystem in McMurdo Sound, Antarctica: biomass, nutrient and production profiles within a dense microalgal bloom. Mar Ecol Prog Ser 127:255-268

Campbell JR, Collin AE (1958) The discoloration of Foxe Basin ice. J Fish Res Board Can 15:1175-1188

Canadian Ice Services (2002) Sea ice climatic atlas-northern Canadian waters 1971-2000. Environment Canada, Ottawa

Canadian Ice Services (2005) Manual of standard procedures for observing and reporting ice conditions (MANICE), 9th edn. Environment Canada, Ottawa

Conover RJ, Mumm N, Bruecker P, MacKenzie S (1999) Sources of urea in arctic seas: seasonal fast ice? Mar Ecol Prog Ser 179:55-69

Cota GF, Pomeroy LR, Harrison WG, Jones EP, Peters F, Sheldon WM Jr, Weingartner TR (1996) Nutrients, primary production and microbial heterotrophy in the southeastern Chukchi Sea: Arctic summer nutrient depletion and heterotrophy. Mar Ecol Prog Ser 135:247-258

Dam HG, Drapeau DT (1995) Coagulation efficiency, organicmatter glues, and the dynamics of particles during a phytoplankton bloom in a mesocosm study. Deep-Sea Res II 42:111-123

Decho A (1990) Microbial exopolymer secretions in ocean environments: their role(s) in food webs and marine processes. Oceanogr Mar Biol Annu Rev 28:73-153

Eicken H (2003) From the microscopic, to the macroscopic, to the regional scale: microstructure and properties of sea ice. In: Thomas DN, Dieckmann GS (eds) Sea ice: an introduction to its physics, chemistry, biology and geology. Blackwell Science, Oxford, p 22-81

Garrison DL, Buck KR (1986) Organism losses during ice melting: a serious bias in sea ice community studies. Polar Biol 6:237-239

Garrison DL, Ackley SF, Buck KR (1983) A physical mechanism for establishing algal populations in frazil ice. Nature 306:363-365

Glibert PM (1993) The interdependence of uptake and release of $\mathrm{NH}_{4}$ and organic nitrogen. Mar Microb Food Webs 7:53-67

Gradinger R, Ikävalko J (1998) Organism incorporation into newly forming Arctic sea ice in the Greenland Sea. J Plankton Res 20:871-886

Grossmann S, Dieckmann GS (1994) Bacterial standing stock, activity, and carbon production during formation and growth of sea ice in the Weddell Sea, Antarctica. Appl Environ Microbiol 60:2746-2753 
Harrison WG, Cota GF, Smith REH (1990) Nitrogen utilization in ice algal communities of Barrow Strait, Northwest Territories, Canada. Mar Ecol Prog Ser 67:275-283

Kanda J, Ziemann DA, Conquest LD, Bienfang PK (1989) Light-dependency of nitrate uptake by phytoplankton over the spring bloom in Auke Bay, Alaska. Mar Biol 103: 563-569

Krembs C, Engel A (2001) Abundance and variability of microorganisms and transparent exopolymer particles across the ice-water interface of melting first-year sea ice in the Laptev Sea (Arctic). Mar Biol 138:173-185

Krembs C, Eicken H, Junge K, Deming JW (2002) High concentrations of exopolymeric substances in Arctic winter sea ice: implications for polar ocean carbon cycle and cryoprotection of diatoms. Deep-Sea Res I 49:2163-2181

Lewis EL, Ponton D, Legendre L, Leblanc B (1996) Springtime sensible heat, nutrients and phytoplankton in the Northwater Polynya, Canadian Arctic. Cont Shelf Res 16: 1775-1792

Magaletti E, Urbani R, Sist P, Ferrari CR, Cicero AM (2004) Abundance and chemical characterization of extracellular carbohydrates released by the marine diatom Cylindrotheca fusiformis under N- and P-limitation. Eur J Phycol 39:133-142

Maguer JF, L'Helguen S, Madec C, Le Corre P (1999) Seasonal patterns of ammonium regeneration from sizefractionated microheterotrophs. Cont Shelf Res 19: 1755-1770

Meiners K, Gradinger R, Fehling J, Civitarese G, Spindler M (2003) Vertical distribution of exopolymer particles in sea ice of the Fram Strait (Arctic) during autumn. Mar Ecol Prog Ser 248:1-13

Meiners K, Brinkmeyer R, Granskog MA, Lindfors A (2004) Abundance, size distribution and bacterial colonization of exopolymer particles in Antarctic sea ice (Bellingshausen Sea). Aquat Microb Ecol 35:283-296

Melnikov IA, Kolosova EG, Welch HE, Zhitina LS (2002) Sea ice biological communities and nutrient dynamics in the Canada Basin of the Arctic Ocean. Deep-Sea Res I 49: 1623-1649

Michel C, Legendre L, Ingram RG, Gosselin M, Levasseur M (1996) Carbon budget of sea-ice algae in spring: evidence of a significant transfer to zooplankton grazers. J Geophys Res 101:18345-18360

Michel C, Nielsen TG, Nozais C, Gosselin M (2002) Significance of sedimentation and grazing by ice micro- and meiofauna for carbon cycling in annual sea ice (northern Baffin Bay). Aquat Microb Ecol 30:57-68

Molina V, Farias L, Eissler Y, Cuevas LA, Morales CE, Escribano R (2005) Ammonium cycling under a strong oxygen gradient associated with the Oxygen Minimum Zone off northern Chile ( $\left.23^{\circ} \mathrm{S}\right)$. Mar Ecol Prog Ser 288:35-43

Nozais C, Gosselin M, Michel C, Tita G (2001) Abundance, biomass, composition and grazing impact of the sea-ice meiofauna in the North Water, northern Baffin Bay. Mar Ecol Prog Ser 217:235-250

Parsons TR, Maita Y, Lalli CM (1984) A manual of chemical and biological methods for seawater analysis. Pergamon Press, Toronto

Parsons TR, Webb DG, Dovey H, Haigh R, Lawrence M, Hopky GE (1988) Production studies in the Mackenzie River-Beaufort Sea estuary. Polar Biol 8:235-239

Passow U (2002a) Production of transparent exopolymer particles (TEP) by phyto- and bacterioplankton. Mar Ecol Prog Ser 236:1-12

Passow U (2002b) Transparent exopolymer particles (TEP) in aquatic environments. Prog Oceanogr 55:287-333
Passow U, Alldredge AL (1994) Distribution, size and bacterial colonization of transparent exopolymer particles (TEP) in the ocean. Mar Ecol Prog Ser 113:185-198

Passow U, Alldredge AL (1995) A dye-binding assay for the spectrophotometric measurement of transparent exopolymer particles (TEP). Limnol Oceanogr 40:1326-1335

Priscu JC, Sullivan CW (1998) Nitrogen metabolism in Antarctic fast-ice microalgal assemblages. Antarct Res Ser 73:147-160

Priscu JC, Lizotte MP, Cota GF, Palmisano AC, Sullivan CW (1991) Comparison of the irradiance response of photosynthesis and nitrogen uptake by sea ice microalgae. Mar Ecol Prog Ser 70:201-210

Redfield AC, Ketchum BH, Richards FA (1963) The influence of organisms on the composition of sea-water. In: Hill MN (ed) The sea, Vol 2. Interscience, New York, p 26-77

Reimnitz E, Marincovich L Jr, McCormick M, Briggs WM (1992) Suspension freezing of bottom sediment and biota in the Northwest Passage and implications for Arctic Ocean sedimentation. Can J Earth Sci 29:693-703

Reimnitz E, Clayton JR, Kempema EW, Payne JR, Weber WS (1993) Interaction of rising frazil with suspended particles: tank experiments with applications to nature. Cold Reg Sci Technol 21:117-135

Riedel A, Michel C, Gosselin M (2006) Seasonal study of seaice exopolymeric substances (EPS) on the Mackenzie Shelf: implications for the transport of sea-ice bacteria and algae. Aquat Microb Ecol 45:195-206

Sherr EB (1988) Direct use of high molecular weight polysaccharides by heterotrophic flagellates. Nature 335:348-351

Sherr EB, Caron DA, Sherr BF (1993) Staining of heterotrophic protists for visualization via epifluorescence microscopy. In: Kemp PF, Sherr BF, Sherr EB, Cole JJ (eds) Handbook of methods in aquatic microbial ecology. Lewis Publications, Boca Raton, FL, p 213-227

Smith DJ, Underwood GJC (1998) Exopolymer production by intertidal epipelic diatoms. Limnol Oceanogr 43:1578-1591

Smith REH, Herman AW (1991) Productivity of sea ice algae: in situ vs. incubator methods. J Mar Syst 2:97-110

Sokal RR, Rohlf FJ (1995) Biometry: the principles and practice of statistics in biological research, 3rd edn. WH Freeman, New York

Tranvik LJ, Sherr EB, Sherr BF (1993) Uptake and utilization of 'colloidal DOM' by heterotrophic flagellates in seawater. Mar Ecol Prog Ser 92:301-309

Underwood GJC, Paterson DM, Parkes RJ (1995) The measurement of microbial carbohydrate exopolymers from intertidal sediments. Limnol Oceanogr 40:1243-1253

von Quillfeldt CH , Ambrose WG Jr, Clough LM (2003) High number of diatom species in first-year ice from the Chukchi Sea. Polar Biol 26:806-818

Weeks WF, Ackley SF (1982) The growth, structure, and properties of sea ice. CRREL Monograph 82-1, Cold Regions Research Engineering Laboratory, Hanover

Weissenberger J, Grossmann S (1998) Experimental formation of sea ice: importance of water circulation and wave action for incorporation of phytoplankton and bacteria. Polar Biol 20:178188

Wheeler PA, Kokkinakis SA (1990) Ammonium recycling limits nitrate use in the oceanic subarctic Pacific. Limnol Oceanogr 35:1267-1278

Zdanowski MK (1988) Bacteria in the pack-ice north of Elephant Island (BIOMASS III, October 1986). Pol Polar Res 9:203-216

Zhang Q, Gradinger R, Spindler M (1998) Dark survival of marine microalgae in the high Arctic (Greenland Sea). Polarforschung 65:111-116 